ГORIGINAL ARTICLE

Volume 16 Issue 22021

DOI: 10.21315/aos2021.16.2.8

ARTICLE INFO

Submitted: $11 / 01 / 2021$

Accepted: 24/06/2021

Online: $22 / 12 / 2021$

\section{Assessment of Fluoride and pH Levels in a Range of Ready-to-Drink Children's Beverages Marketed in Malaysia}

\author{
Aira Syazleen Ahmada,b, Nor Azlida Mohd Nor ${ }^{\mathrm{r} *}$, Nadia Afiqah Ahmad ${ }^{\mathrm{b}}$, \\ Zamros Yuzadi Mohd Yusof ${ }^{b}$, Ivor G. Chestnutt ${ }^{c}$
}
${ }^{a}$ Oral Health Programme, Ministry of Health, Federal Government Administrative Centre, 62590 Putrajaya, Malaysia
${ }^{b}$ Department of Community Oral Health and Clinical Prevention, Faculty of Dentistry, Universiti Malaya, 50603 Kuala Lumpur, Malaysia

'Department of Applied Clinical Research and Dental Public Health, Cardiff University School of Dentistry, Heath Park, Cardiff CF14 4XY, United Kingdom

${ }^{\star}$ Corresponding author: azlida@um.edu.my

To cite this article: Ahmad AS, Mohd Nor NA, Ahmad NA, Mohd Yusof ZY, Chestnutt IG (2021). Assessment of fuoride and $\mathrm{pH}$ levels in a range of ready-to-drink children's beverages marketed in Malaysia. Arch Orofac Sci, 16(2): 177-189. https://doi.org/10.21315/aos2021.16.2.8

To link to this article: https://doi.org/10.21315/aos2021.16.2.8

\begin{abstract}
This study aimed to determine the fluoride and $\mathrm{pH}$ levels of beverages likely to be consumed by children in Malaysia and to estimate daily fluoride intake from consumption of these beverages. A convenience sampling of 120 ready-to-drink beverages were purchased and categorised into 11 groups (UHT recombined milk, fresh milk [pasteurised], cultured milk [probiotic], yogurt beverages, fresh fruit juices, fruit flavoured beverages, soy-based beverages, malt-based beverages, tea, carbonated beverages and bottled waters). Fluoride concentration was measured using a fluoride ion-selective electrode while the $\mathrm{pH}$ level was measured using a $\mathrm{pH}$ meter. The fluoride concentration in the beverages ranged from $0.02 \pm 0.00 \mathrm{mg} / \mathrm{L}$ to $2.77 \pm 0.06 \mathrm{mg} / \mathrm{L}$. Tea was found to have the highest fluoride concentration. The intake of fluoride from consumption of other types of beverages is below the lowest-observed-adverseeffect level (except tea). The $\mathrm{pH}$ of the beverages included in the study ranged from 2.20 \pm 0.01 to 7.76 \pm 0.00 . Carbonated beverages (mean $\mathrm{pH}: 2.98 \pm 0.50$ ) were found to be extremely acidic followed

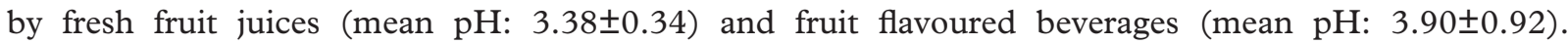
The correlation between fluoride and $\mathrm{pH}$ levels was weak, $\tau=0.058$ and not statistically significant $(p<0.35)$. The majority of the beverages had a low fluoride level and their consumption is unlikely to cause fluorosis except for tea. Almost half of the beverages had a low $\mathrm{pH}$ level with carbonated beverages being the most acidic.
\end{abstract}

Keywords: Beverages; dental erosion; dental fluorosis; fluoride; $p H$ 


\section{INTRODUCTION}

The intake of beverages can influence a child's quality of diet in a positive or negative manner depending on the types and amount of beverages consumed. Over the past decades, trends in beverage consumption among children have changed where a decreasing trend in the consumption of water and dairy beverages and an increasing trend in the consumption of sugar-sweetened beverages and soft drinks were observed (Fulgoni \& Quann, 2012). As far as dental health is concerned, high consumption of sugary drinks can lead to dental caries and high consumption of acidic drinks can lead to dental erosion (Chowdhury et al., 2019). In addition, beverages may also contain fluoride depending on the sources of water used to manufacture the products. Beverages with fluoride levels between $0.5 \mathrm{mg} / \mathrm{L}$ to $1.5 \mathrm{mg} / \mathrm{L}$ could contribute to the "halo effect" of water fluoridation. This can happen when beverages manufactured in fluoridated areas are transported and consumed by populations in non-fluoridated areas (Victory et al., 2017). As a result, the availability of fluoride in beverages could potentially benefit those living in non-fluoridated areas for the purpose of caries prevention. However, excessive ingestion of fluoride during tooth development in early childhood can lead to a defect in the enamel structure development known as dental fluorosis. This is represented by the appearance of white or brown lines, spots, or flecks on the surfaces of the teeth with weaker enamel structure in severe cases (Browne et al., 2005).

Beverages with low $\mathrm{pH}$ levels $(\mathrm{pH}<4.00)$ can exert a detrimental effect on the tooth structure through their erosive properties (Reddy et al., 2016). Epidemiological data showed that there was a high prevalence of dental erosion, up to $79.0 \%$ among $2-5$ years old children who consumed high amounts of acidic beverages such as carbonated drinks and fruit juices (Mantonanaki et al., 2013). These beverages are sold widely in the market. Access to these products is made even easier by the availability of online shopping facilities (Ni Mhurchu et al., 2013). Some of the beverages include certain types of acids, i.e., phosphoric acid, and citric acid and most of them are often sweetened with excess sugars. Thus, high intake of such beverages can lead to tooth erosion and dental caries (Reddy et al., 2016; Chowdhury et al., 2019).

Many previous studies have reported on the fluoride and $\mathrm{pH}$ levels contained in beverages (Reddy et al., 2016; Zohoori \& Maguire, 2018; Chowdhury et al., 2019). These studies were done to provide the public with information on the fluoride and $\mathrm{pH}$ levels contained in the beverages whose information is missing from the labels. In the UK, researchers have urged beverage manufacturers to label their products with information on the fluoride and $\mathrm{pH}$ levels. However, many manufacturers have been reluctant to do so because of the extra financial cost incurred for measuring the fluoride and $\mathrm{pH}$ levels in their food and drink products (Zohoori \& Maguire, 2018). Therefore, the only way to measure the fluoride and $\mathrm{pH}$ levels in beverages is by conducting separate laboratory tests. In response to the increasing trend of beverages consumption in children in Malaysia and the lack of information on the fluoride and $\mathrm{pH}$ levels in these beverages, this study aimed to determine the fluoride and $\mathrm{pH}$ levels in a broad selection of children beverages sold in Malaysia; and to estimate daily fluoride intake from consumption of these beverages. The findings will be useful to estimate the total daily fluoride intake among young children in Malaysia in order to prevent dental fluorosis. In addition, the information on fluoride and $\mathrm{pH}$ levels in different types of beverages will assist medical and dental health professionals to provide appropriate oral health education and dietary advice to mothers with small children with respect to beverage consumption and their effects on oral health. 


\section{MATERIALS AND METHODS}

\section{Sampling}

In the present study, a convenience sample of 120 children's beverages were purchased from three major supermarkets; Giant, Tesco and AEON located in Nilai, Negeri Sembilan, Malaysia. The sampling frame consisted of popular supermarkets $(n=6)$ in Nilai. Of these, only three major retailers with supermarkets throughout Malaysia and their provision of online shopping facilities were selected. With the availability of online shopping platform, these products represent the majority of children beverages sold in the Malaysian market during the data collection period (January to March 2019).

Two methods were used to determine whether the beverages were marketed for children. First, children's beverages were identified based on their packaging. This included children-oriented packaging, i.e., with cartoon images or the manufacturers labelling the product as "children's product" or products with an age indication. The second method was based on the literature on popular beverages among children (Opydo-Szymaczek \& Opydo, 2010; Zahid et al., 2017; Rodríguez et al., 2018). Only ready-to-drink children's beverages were included in this study. Alcoholic beverages, semi-solid beverages, energy boosters and caffeinated beverages were excluded.

The samples were grouped into 11 main groups of beverages: UHT recombined milk, fresh milk (pasteurised), cultured milk (probiotic), yogurt beverages, fresh fruit juice, fruit flavoured beverages, soybased beverages, malt-based beverages, tea, carbonated beverages and bottled waters.

\section{Sample Preparation and Analysis}

The samples were kept in their original packaging at the same temperature as specified by the manufacturers (room or cold temperature) until before the fluoride analysis was undertaken. A blind measurement of fluoride and $\mathrm{pH}$ levels for each beverage was carried out by a single person who was unaware of which beverage was being tested in order to prevent assessment bias. First, the researcher placed a sample of each beverage in a beaker and labelled it with a code. Then, the beverage in the beaker was tested for fluoride and $\mathrm{pH}$ levels by a laboratory expert who was blinded to the types of beverages.

All samples were tested at room temperature $\left(27^{\circ} \mathrm{C}\right)$ to minimise the effect of different surrounding temperatures on the readings. Beverages stored at room temperature were tested immediately after they were opened. However, cold beverages, i.e., fresh fruit juices and fresh milks were allowed to remain outside the refrigerator until the temperatures had risen to the room temperature before they were tested for fluoride and $\mathrm{pH}$ levels.

A direct method of fluoride ion selective electrode was used to measure fluoride levels in the beverages (Martínez-Mier et al., 2011). A Thermo Scientific Orion 9609BNWP (Thermo Fisher Scientific Inc, US) fluoride ion selective electrode was used as the measurement tool. Prior to sample testing, the machine was calibrated for accuracy. Calibration was performed using $0.1 \mathrm{mg} / \mathrm{L}$ to $1.0 \mathrm{mg} / \mathrm{L}$ fluoride standards with total ionic strength adjustment buffer (TISAB) II. Only fresh standards were used for calibration in each session. To measure the fluoride concentration, $20 \mathrm{ml}$ of TISAB II was added to $20 \mathrm{ml}$ sample of each beverage. Samples were stirred for one minute using Eyela Magnetic Stirrer RC-2 (Eyela, US). The fluoride ion selective electrode was immersed into the solution to check for fluoride level using Orion Versa Star Advanced Electrochemistry Meter, (Thermo Fisher Scientific Inc, US) until a stable digital reading was obtained. The whole process took about five minutes per sample reading. The fluoride content of each sample was obtained from the average of triplicate readings. 
To measure the $\mathrm{pH}$ levels, an Automatic Temperature Compensation (ATC) Probe, (Jenco Instruments Inc, US) was immersed into $40 \mathrm{ml}$ of samples and the $\mathrm{pH}$ level was measured using a Jenco Vision Plus pH6175, (Jenco Instruments Inc, US). Dual point calibration was carried out using buffer solutions of $\mathrm{pH} 6.86$ and $\mathrm{pH} 4.00$ and only fresh standards were used for calibration before each session began. The $\mathrm{pH}$ level of each sample was obtained from the average of triplicate readings.

All instruments in the experiment were washed using deionised water and dried with a paper towel between measurements to prevent cross-contamination between samples or standards. To ensure the accuracy of readings, recalibration was done after every six measurements. Reproducibility of the method was assessed by re-analysis of $30 \%$ of the samples $(n=40)$. For re-analysis purpose, different packet beverages of the same types of beverages were tested. The measurements showed that the electrode readings were reproducible.

\section{Data Analysis}

All data were entered and analysed using IBM Statistical Package for Social Science (SPSS) version 24 software (24.0, IBM Corp, Armonk, NY). Descriptive statistics analysis was performed and data were presented using mean and standard deviation. For the purpose of data presentation, the values of $0.40 \mathrm{mg} / \mathrm{L}$ and $0.60 \mathrm{mg} / \mathrm{L}$ were used as cut-off points to establish categories that are consistent with the optimum fluoride levels in the public water supply in Malaysia (low level, $F<0.4 \mathrm{mg} / \mathrm{L}$; optimum level, $F=0.4-$ $0.6 \mathrm{mg} / \mathrm{L}$; high level, $F>0.6 \mathrm{mg} / \mathrm{L}$ ) (Malaysian Dental Council, 2009). The mean $\mathrm{pH}$ level in the beverages was further categorised based on their chemical erosive potentials; (1) extremely erosive $(\mathrm{pH} \leq 2.99),(2)$ erosive $(3.00 \leq \mathrm{pH} \leq$ 3.99), and (3) minimally erosive (4.00 $\leq$ $\mathrm{pH} \leq$ 6.99) (Reddy et al., 2016). Test of normality showed that the outcome data were not normally distributed. As a result, Kendall's tau-b test was used to measure the association between fluoride concentration and $\mathrm{pH}$ levels in the samples. The $p$ value $<0.05$ was set as the level of statistical significance.

The equation used to calculate the estimated daily fluoride intake from beverages consumption was adapted from a previous study (Liu et al., 2017). The estimated daily fluoride intake from beverages consumption (mg/day) was calculated using the mean fluoride level in the beverages, and the daily beverage consumption ranged from $253 \mathrm{ml} /$ day (min) to $633 \mathrm{ml} /$ day (max) as reported by the Institute of Medicine (Institute of Medicine, 2005). The estimated daily fluoride intake per $\mathrm{kg}$ body weight $(\mathrm{mg} / \mathrm{kg}$ bw/day) was calculated using average child weights ( $\leq 4$ years) from the Malaysian reference weight (Bong et al., 2015) and the World Health Organization (WHO) reference weight (WHO Multicentre Growth Reference Study Group, 2006). The Institute of Medicine daily beverage consumption range was used as there is no local data available for young children in Malaysia. The minimum and maximum values of beverage consumption were used to reflect on the lowest and highest level of estimated fluoride ingestion from beverage consumption.

\section{RESULTS}

Of the 120 samples, $76.7 \%$ were locally manufactured and $23.3 \%$ were imported. The imported beverages were mainly from Thailand $(n=12)$, followed by Singapore $(n=3)$ and Australia $(n=3)$. Others were from Indonesia, Vietnam, South Africa, Bangladesh, Turkey, Cyprus, France, Italy, Austria and US; with one product each. None of the beverages stated the fluoride or acidity levels on their labels. In this study, the analysed samples were divided into 11 groups of beverages. 


\section{Fluoride Levels in Beverages}

Table 1 shows the fluoride levels of the samples. The overall mean fluoride level (without differentiating the group of beverages) was $0.33 \pm 0.37 \mathrm{mg} / \mathrm{L}$, and ranged from 0.02 to $2.77 \mathrm{mg} / \mathrm{L}$. The majority of the samples had a low fluoride concentration. Only $10 \%$ had a fluoride level of more than $0.60 \mathrm{mg} / \mathrm{L}$ (Fig. 1). These were teas and malt-based beverages. Tea samples were found to have the highest variations in fluoride levels ranging from 0.11 to $2.77 \mathrm{mg} / \mathrm{L}$ (see Table 1). In terms of maltbased beverages, the mean fluoride level was $0.65 \pm 0.36 \mathrm{mg} / \mathrm{L}$ and the levels ranged from 0.05 to $0.96 \mathrm{mg} / \mathrm{L}$ (see Table 1). Only one bottled water had a high fluoride level $(1.60 \pm 0.00 \mathrm{mg} / \mathrm{L})$ with the remaining samples had a low fluoride level. There was a higher fluoride level in local beverages (mean $=0.38 \mathrm{mg} / \mathrm{L}, \quad \mathrm{SD}=0.40$ ) than imported beverages (mean $=0.16 \mathrm{mg} / \mathrm{L}$, $\mathrm{SD}=0.20)($ see Table 2$)$.

\section{Estimated Fluoride Ingestion from Beverages}

Table 3 shows the amount of fluoride ingested thorough consumption of the beverages. This was estimated at $0.006 \mathrm{mg} /$ $\mathrm{kg}$ bw/day to $0.015 \mathrm{mg} / \mathrm{kg}$ bw/day using Malaysian children's body weight (14-15 $\mathrm{kg})$. The amount was lower $(0.005 \mathrm{mg} /$ $\mathrm{kg}$ bw/day to $0.013 \mathrm{mg} / \mathrm{kg}$ bw/day) when calculated using global reference body weight from the WHO $(16 \mathrm{~kg})$.

Table 1 Mean fluoride level in different groups of beverages $(n=120)$

\begin{tabular}{lcccc} 
& & & \multicolumn{2}{c}{ Fluoride level (mg/L) } \\
\cline { 3 - 5 } Groups of beverages & Sample $(\boldsymbol{n})$ & Fluoride range $(\mathbf{m g} / \mathbf{L})$ & Mean & SD \\
UHT recombined milk & 11 & $0.02-0.49$ & 0.26 & 0.15 \\
Fresh milk (pasteurised) & 12 & $0.04-0.44$ & 0.14 & 0.14 \\
Cultured milk (probiotic) & 7 & $0.05-0.59$ & 0.34 & 0.21 \\
Yogurt beverages & 6 & $0.08-0.56$ & 0.32 & 0.19 \\
Fresh fruit juices & 16 & $0.04-0.48$ & 0.18 & 0.17 \\
Fruit flavoured beverages & 22 & $0.03-0.58$ & 0.20 & 0.18 \\
Soy-based beverages & 13 & $0.04-0.69$ & 0.38 & 0.19 \\
Malt-based beverages & 5 & $0.05-0.96$ & 0.65 & 0.36 \\
Teas & 11 & $0.11-2.77$ & 0.89 & 0.77 \\
Carbonated beverages & 9 & $0.03-0.45$ & 0.10 & 0.14 \\
Bottled water & 8 & $0.07-1.60$ & 0.52 & 0.49 \\
\hline Total & 120 & $0.02-2.77$ & 0.33 & 0.37 \\
\hline
\end{tabular}

Table 2 Summary data of fluoride and $\mathrm{pH}$ levels in local and imported beverages $(n=120)$

\begin{tabular}{lccccc}
\multirow{2}{*}{ Value } & \multicolumn{2}{c}{ Fluoride $(\mathbf{m g} / \mathbf{L})$} & & \multicolumn{2}{c}{$\mathbf{p H}$} \\
\cline { 2 - 3 } \cline { 5 - 6 } Min & Local $(\boldsymbol{n}=\mathbf{9 2})$ & Import $(\boldsymbol{n}=\mathbf{2 8})$ & & Local $(\boldsymbol{n}=\mathbf{9 2})$ & Import $(\boldsymbol{n}=\mathbf{2 8})$ \\
Max & 0.02 & 0.04 & & 2.20 & 2.70 \\
Mean & 2.77 & 0.87 & & 7.58 & 7.76 \\
SD & 0.38 & 0.16 & & 4.86 & 4.94 \\
\hline
\end{tabular}




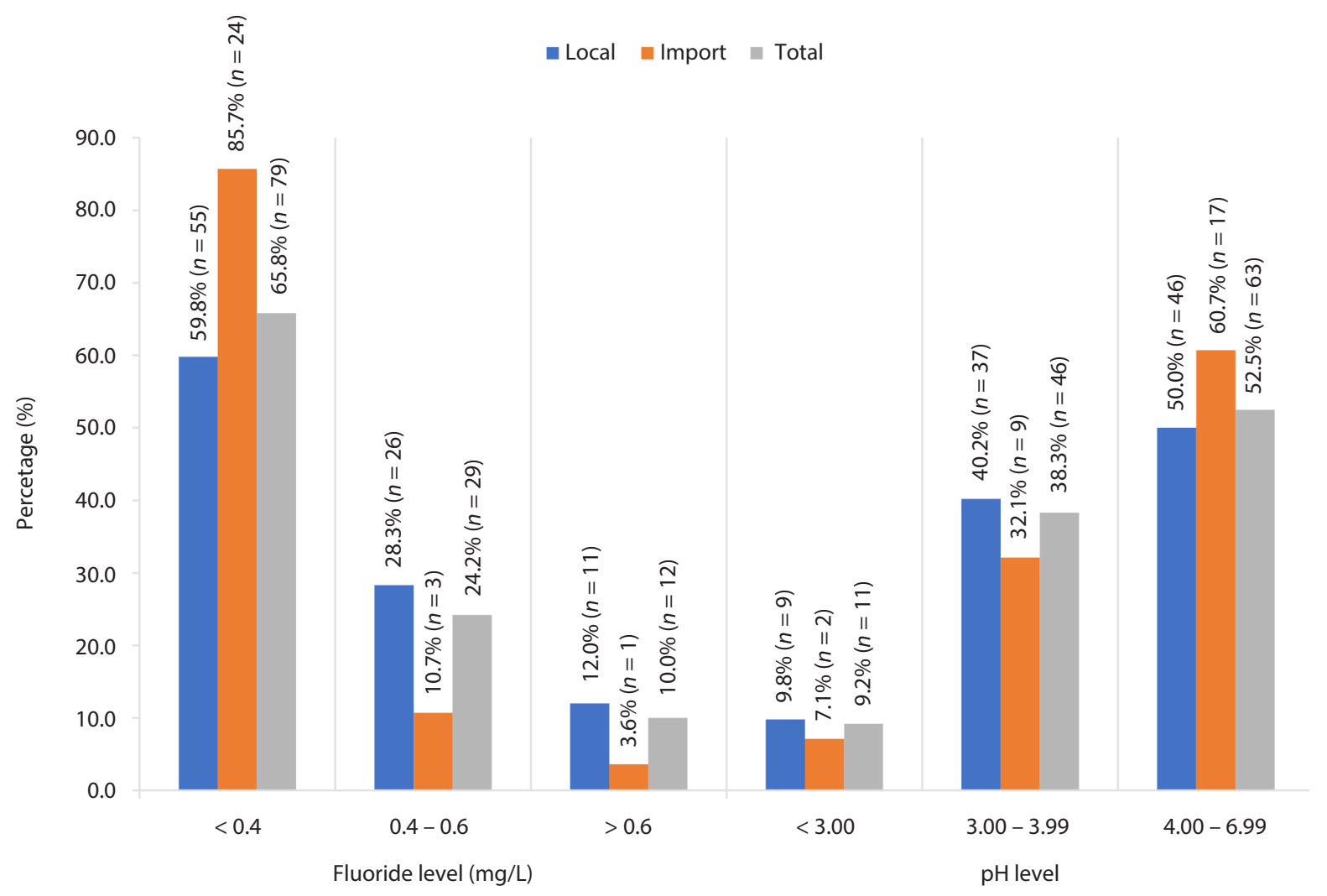

Fig. 1 Summary data of fluoride and pH levels in local and imported beverage samples.

Table 3 Estimated amount of fluoride ingested from beverages

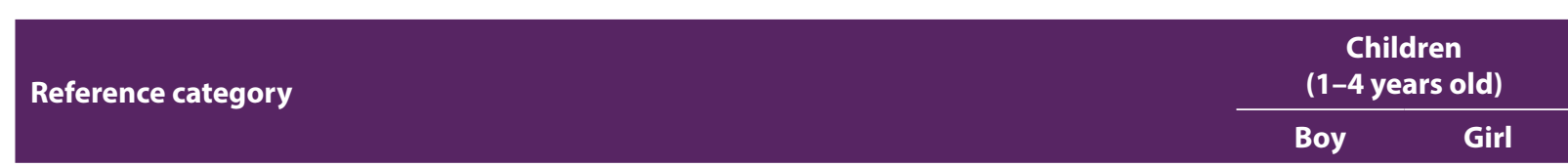

Body weight $(\mathrm{kg})$

Malaysian growth reference ${ }^{\text {a }}$

WHO growth reference ${ }^{b}$

Range beverages consumption ( $\mathrm{ml} /$ day)

Estimated maximum amount of fluoride ingested from beverages (total mean $=0.33 \mathrm{mg} / \mathrm{L}$ )

$\mathrm{mg} /$ day

$\mathrm{mg} / \mathrm{kg} \mathrm{bw/day}$

\begin{tabular}{lr}
15 & 14 \\
16 & 16 \\
\multicolumn{2}{|c}{$253-633$}
\end{tabular}

0.083

$0.006^{\mathrm{a}}$ $0.015^{\mathrm{a}}$

$0.005^{\mathrm{b}}$

Notes:

${ }^{a}$ Calculation based on body weight from the Malaysian children growth reference (Bong et al., 2015).

${ }^{b}$ Calculation based on body weight from the WHO growth reference (WHO Multicentre Growth Reference Study Group, 2006).

'Recommended daily beverage consumption for children 1-4 years old (Institute of Medicine, 2005). 


\section{pH Levels in Beverages}

There was a wide range of $\mathrm{pH}$ levels between and within the different groups of beverages with $\mathrm{pH}$ levels ranging from 2.20 to 7.76 . Just under half of the beverages $(47.5 \%)$ had a $\mathrm{pH}$ level lower than 4.00 (Fig. 1). Of these, carbonated beverages were found to be extremely erosive (mean $\mathrm{pH}: 2.98 \pm 0.50$; range: 2.20 to 3.76 ), followed by fresh fruit juices (mean pH: 3.38 \pm 0.34 ; range: 2.70 to 3.97) and fruit flavoured beverages (mean $\mathrm{pH}$ : $3.90 \pm 0.92$; range: 2.53 to 5.34 ) with some erosive potentials (Table 4). All milkbased beverages had $\mathrm{pH}$ levels approaching the neutral $\mathrm{pH}$ level (mean $\mathrm{pH}$ : $6.62 \pm 0.14$; range: 6.24 to 6.89 ) except for cultured-milk (probiotic) beverages (mean pH: $3.62 \pm 0.14$; range: 3.51 to 3.84 ) and yogurt beverages (mean $\mathrm{pH}: 4.11 \pm 0.15$; range: 3.95 to 4.30 ) which were more acidic. There was little difference in $\mathrm{pH}$ levels between imported and local beverages (Table 2). Two groups of beverages were found to have the highest within-group variations in $\mathrm{pH}$ levels namely tea-based beverages and bottled waters.

Table 4 Mean pH level in different groups of beverages $(n=120)$

\begin{tabular}{lcccc} 
& & & \multicolumn{2}{c}{ pH level } \\
\cline { 5 - 5 } Groups of beverages & Sample $(\boldsymbol{n})$ & pH range & Mean & SD \\
\cline { 5 - 5 } UHT recombined milk & 11 & $6.39-6.89$ & 6.61 & 0.14 \\
Fresh milk (pasteurised) & 12 & $6.24-6.74$ & 6.62 & 0.14 \\
Cultured milk (probiotic) & 7 & $3.51-3.84$ & 3.62 & 0.14 \\
Yogurt beverages & 6 & $3.95-4.30$ & 4.11 & 0.15 \\
Fresh fruit juices & 16 & $2.70-3.97$ & 3.38 & 0.34 \\
Fruit flavoured beverages & 22 & $2.53-5.34$ & 3.90 & 0.92 \\
Soy-based beverages & 13 & $6.24-7.05$ & 6.62 & 0.24 \\
Malt-based beverages & 5 & $5.98-6.95$ & 6.55 & 0.40 \\
Teas & 11 & $2.86-6.11$ & 4.24 & 1.32 \\
Carbonated beverages & 9 & $2.20-3.76$ & 2.98 & 0.50 \\
Bottled water & 8 & $2.87-7.76$ & 6.38 & 2.05 \\
\hline Total & $\mathbf{1 2 0}$ & $\mathbf{2 . 2 0 - 7 . 7 6}$ & $\mathbf{4 . 8 8}$ & $\mathbf{1 . 6 4}$ \\
\hline
\end{tabular}

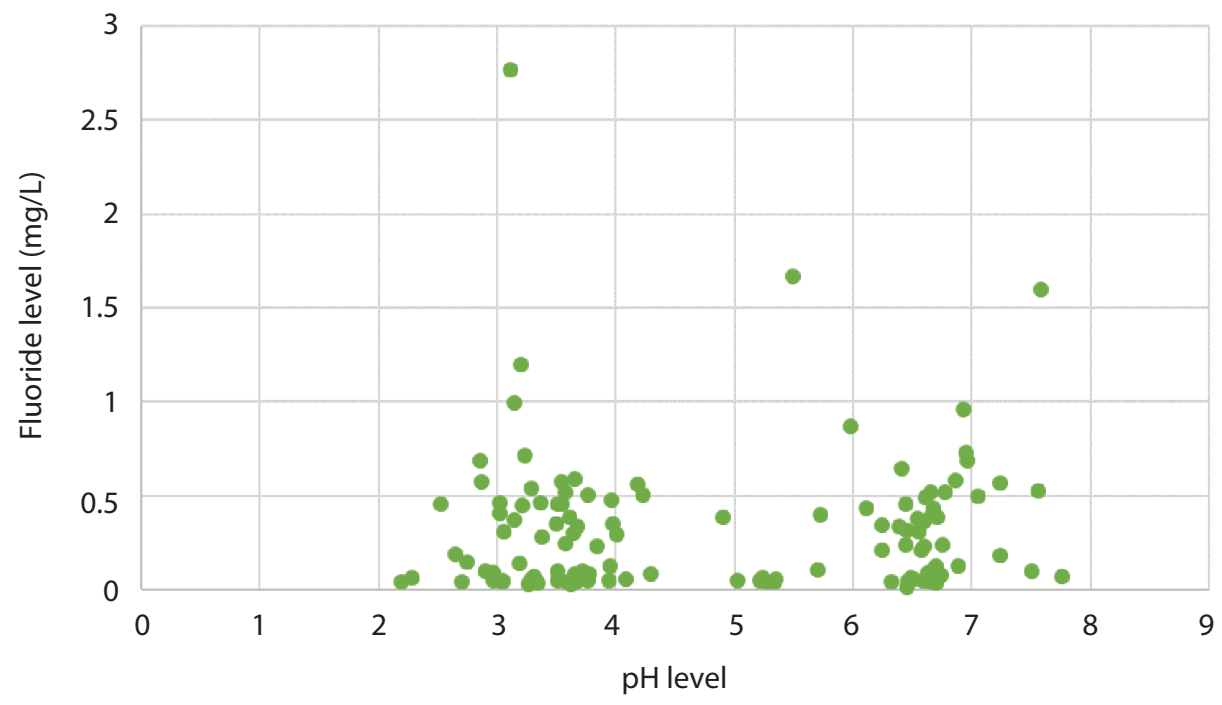

Fig. 2 Scatter plot of fluoride levels against $\mathrm{pH}$ levels of sampled beverages. 
The mean $\mathrm{pH}$ levels in tea-based beverages ranged from $2.86 \pm 0.00$ to $6.11 \pm 0.01$ (Table 4). There were six tea brands (fruit flavour based such as lemon, peach and grape) that were found to have erosive to extremely erosive potentials $(\mathrm{pH}<4.00)$. The range of $\mathrm{pH}$ levels in bottled waters was $2.87 \pm 0.01$ to $7.76 \pm 0.00$ (Table 4 ). Most of the bottled waters were alkaline except for the two lightly carbonated bottled waters (mean pH: $2.87 \pm 0.01$ and $3.29 \pm 0.01$ ). Fig. 2 shows the scatter plot of fluoride against $\mathrm{pH}$ levels of the beverages. There was a weak positive, but non-statistically significant $(p<0.350)$ correlation between fluoride and $\mathrm{pH}$ levels $(\tau=0.058)$.

\section{DISCUSSION}

This study aimed to assess the fluoride and $\mathrm{pH}$ levels in children's beverages available in the Malaysian market and to estimate the daily intake of fluoride from consumption of these drinks. The findings showed that there was a wide range of variations in the fluoride and $\mathrm{pH}$ levels in children's beverages sold in the Malaysian market.

\section{Fluoride Levels in the Beverages and Implications for Oral Health}

Despite variations in fluoride levels between and within the different groups of beverages, the majority of the beverages had low fluoride levels. Only tea and malt-based beverages were found to have higher fluoride levels than other groups of beverages in the study. High fluoride levels in tea drinks found in this study were similar to findings in other related studies conducted in other countries (Opydo-Szymaczek \& Opydo, 2010; Fojo et al., 2013; Rodríguez et al., 2018). Tea drinks contain a high amount of fluoride mainly due to the fact that tea leaves accumulate fluoride from the soil. The mean fluoride level in tea drinks in the present study $(0.89 \pm 0.77 \mathrm{mg} / \mathrm{L})$ was similar to that found in a study in Thailand $(0.81 \pm 0.51 \mathrm{mg} / \mathrm{L}) \quad$ (Rirattanapong \& Rirattanapong, 2017) but higher than fluoride levels found in tea drinks sold in Poland and Portugal (Opydo-Szymaczek \& Opydo, 2010; Fojo et al., 2013). In contrast, a higher mean fluoride level in tea drinks was also reported in a previous local study in $2014(13.02 \pm 0.23 \mathrm{mg} / \mathrm{L}$ ) (Rahim et al., 2014). However, the difference in the findings between that and the present study could be due to the different types of tea drinks being tested and the different methods used in measuring fluoride levels where a photometer was used in the earlier study. Tea drinks included in the present study were ready-to-drink products targeted for children's consumption, and the fluoride levels were measured using the gold standard ion-selective electrode for fluoride analysis method established in the literature (Martínez-Mier et al., 2011). In this method, errors in measurement were minimised as the fluoride electrode was linked directly to a digital fluoride reader.

In addition to tea, malt beverages were also found to have a higher mean fluoride level (mean: $0.65 \pm 0.36 \mathrm{mg} / \mathrm{L}$ ) than the recommended national standard for fluoride level in the public water supply. Comparison of fluoride levels in malt beverages in this study with other published studies was limited due to the fact that past studies on the subject were mostly focused on juices and milk drinks and did not include malt-based beverages. By definition, malt drinks are malt-based foods manufactured by mixing malt with other cereal and legume flours with or without whole milk or milk powder and/or cocoa powder (Gan et al., 2019). This type of beverage is popular among young children in Malaysia and is marketed as a nutritious beverage (Jan Mohamed et al., 2015).

A potential reason for the wide variations in fluoride levels in the beverages could be due to the variations in fluoride levels in the water source used at the manufacturing sites. The water sources could come from artificially fluoridated areas, water with natural fluoride content and water coming from different types of water filters that may or may not remove fluoride (depending on 
the types of filtration system). Although the optimum level of fluoride in Malaysian public water supply is $0.5 \pm 0.1 \mathrm{mg} / \mathrm{L}$, fluoride level in the water may not be consistent throughout the region and may vary by geographical areas (Shaharuddin et al., 2009). As drink manufacturers may have multiple production sites, their water sources may come from different areas and therefore the beverages may contain different fluoride levels depending on the manufacturing sites where they were produced (Liu et al., 2017; Townsend et al., 2019). No clear patterns were observed between drinks produced inside or outside Malaysia. Most of the imported drinks had low fluoride levels, although they were imported from countries with a water fluoridation programme such as Thailand, Australia and Singapore. However, the results should be interpreted with caution as the samples of beverages produced outside Malaysia were relatively few in this study which reflected their availability in the local market during the data collection period. In addition, the variations in fluoride levels in the beverages could also be due to the different fluoride levels contained in fruits used to make fruit juice beverages. A study in Spain reported that certain types of fruit juices such as grape juice has a higher fluoride level $(1.14 \mathrm{mg} / \mathrm{L})$ than other juice products made from carrots $(0.07 \mathrm{mg} / \mathrm{L})$ or apricot $(0.06 \mathrm{mg} / \mathrm{L})$ (Rodríguez et al., 2018). Meanwhile, a study in the UK reported that ready-to-feed infant juices contained fluoride ranging from 0.05 to $0.15 \mathrm{mg} / \mathrm{L}$ with the highest fluoride level found in pear and peach juices (Maguire et al., 2012).

The estimated amount of ingested fluoride from beverages per body weight alone was low and did not exceed the lowest-observedadverse-effect level of fluoride for young children $(0.1 \mathrm{mg} / \mathrm{L})$. Therefore, a potential association with dental fluorosis in the permanent dentition upon consumption of these beverages (except tea drinks) is highly unlikely. Similar results were reported from a study conducted in Heilongjiang Province, North-east China (Liu et al., 2017). However, the present study found that certain types of tea-based beverages had high concentration of fluoride $(2.77 \mathrm{mg} / \mathrm{L})$ that exceeds the recommended level of fluoride in the water supply by local ( 0.4 to $0.6 \mathrm{mg} / \mathrm{L}$ ) and the WHO guidelines (0.5 to $1.5 \mathrm{mg} / \mathrm{L})$ (Malaysian Dental Council, 2009; World Health Organization, 2011). Excessive consumption of this type of beverages in addition to exposure to dietary and nondietary sources of fluoride, i.e., toothpaste and/or fluoride varnish during childhood may increase the risk of dental fluorosis. The critical period for dental fluorosis development in the permanent teeth is in the first 2-3 years of life for upper central incisors and the first 6-8 years of life for posterior teeth (Buzalaf \& Levy, 2011). It is known that a low level of fluoride in the oral cavity is beneficial for caries prevention. However too much exposure to fluoride may increase the risk of developing fluorosis. Therefore, continuous monitoring of fluoride intake during childhood is important to maximise the benefit of fluoride for caries prevention and minimise the risk of fluorosis.

\section{pH Levels in the Beverages and Implications for Oral Health}

In terms of $\mathrm{pH}$ level, the carbonated beverages were found to be the most acidic (extremely erosive) followed by the fresh fruit juices and probiotic beverages. The mean $\mathrm{pH}$ level of carbonated beverages in the present study $(2.98 \pm 0.50)$ was in agreement with the findings in most studies on the erosive potential of carbonated beverages worldwide (Cochrane et al., 2009; Idris et al., 2016; Omid et al., 2016). Carbonated beverages are acidic due to the formation of carbonic acid $\left(\mathrm{H}_{2} \mathrm{CO}_{3}\right)$ in a reaction catalysed by carbonic anhydrase enzyme (Reddy et al., 2016). The fizziness property of carbonated beverages was subject to the concentration of carbon dioxide dissolved and its ability to change from liquid phase to form bubbles (Descoins et al., 2006). At the same time, a low $\mathrm{pH}$ level was also found in two of the lightly carbonated bottled waters also known as sparkling water. This may be due to the carbonation process in the making 
of the products which takes place at the manufacturing site and/or the naturally occurring mineral acids in spring waters from which they are made. Similar findings were also reported in studies conducted in the UK (Brown et al., 2007) and Australia (Cochrane et al., 2009).

Data on high acidity of fresh fruit juices and fruit flavoured beverages found in the present study support similar findings reported by other investigators in the US (Reddy et al., 2016) and UK (Maguire et al., 2012). This could be attributed to the acid ingredients which are added to the beverages at the manufacturing site in addition to the fruit's natural acids. Acids are added to beverages and compose a flavour profile giving the beverages a distinctive taste. For example, phosphoric acid and citric acid are added to beverages to impart a tangy flavour, act as a preservative, and enhance the intrinsic flavour. However, acids also occurred naturally in fruits. For example, citrus fruits such as lemon, orange, mango and grapes have both citric acid and ascorbic acid (vitamin C) (Reddy et al., 2016). Other seasonal fruits such as apples, pears and cherries contain malic acids. Those additional acids on top of natural fruit acids have contributed to the decrease in $\mathrm{pH}$ level. As a result, high consumption of this type of beverage may increase the risk of dental erosion (Chowdhury et al., 2019). Additionally, as far as dental health is concerned, both the carbonated and flavoured juices are often sweetened and contain high amount of sugars. The combination of high sugar levels and high acidity of carbonated drinks and fruit juices have made the products highly cariogenic which lead to dental caries over a short period of time if consumed in high quantities (Chowdhury et al., 2019). In children, the consumption of these types of beverages should be limited to once daily preferably during one of the main meals when the saliva buffering capacity is at its peak (Moynihan, 2002). Sipping the drinks throughout the day is not recommended as this habit will expose the teeth to sugars and high acidity over a long period of time which may lead to severe early childhood caries (Moynihan, 2002).

The cultured milk (probiotic) beverages were also found to have low $\mathrm{pH}$ levels. One of the reasons is that these drinks often contain pieces of citrus fruits which are acidic in nature. In addition, cultured milk beverages are acidic because the starters used in the fermentation process of carbohydrates consist of homofermentative mesophilic lactic acid bacteria (Shiby \& Mishra, 2013). Parents should be made aware of the low $\mathrm{pH}$ levels in cultured milk drinks as they tend to be quite popular among children and are often marketed as healthy products.

There was no significant association between fluoride and $\mathrm{pH}$ levels of the beverages in the present study. In view of the finding, the fluoride content in the beverages is unlikely to have a significant effect on the acidity of the beverages and vice versa. Similar findings were also reported by Larsen \& Richards (2002) where fluoride was not able to reduce the erosive property of soft drinks for children.

Findings from the present study will be useful in assisting health professionals to educate parents with respect to the potential sources of fluoride intake in children especially at a young age. Knowledge on the acidity of different types of beverages is equally important in preventing dental erosion and managing patients with such a condition.

\section{Study Strengths and Limitations}

The strength of this study was that it included a wide variety of beverages tested for fluoride and $\mathrm{pH}$ levels. Furthermore, the respective test for each drink was conducted in triplicate to ensure the results obtained were precise and reliable. On the other hand, this study only included beverages purchased from one geographical area. However, efforts had been made to improve the external validity of the findings by selecting supermarkets that also provide 
online shopping, thus making the beverages accessible to a wider Malaysian population. The beverages were marketed in different types of packaging such as box cartridge, can, glass bottle and aluminium pouch. All these containers may potentially be a confounder for measuring fluoride level (Liu et al., 2017).

\section{CONCLUSION}

Beverages sold in the Malaysian market have a wide range of fluoride and $\mathrm{pH}$ levels. The majority had low fluoride levels except for tea and malt-based beverages while fewer types had low $\mathrm{pH}$ levels with carbonated beverages being the most acidic, followed by fruitbased beverages. There was a weak positive correlation between fluoride concentration and $\mathrm{pH}$ levels indicating fluoride content is unlikely to have an effect on the acidity of the beverages. The findings will be useful in dental health education and dietary advice for mothers with small children as well as patients with high intakes of certain types of beverages.

\section{ACKNOWLEDGEMENTS}

This study was financially supported by the Research University Grant, Universiti Malaya (Grant number: RF001E-2018).

\section{REFERENCES}

Bong Y, Shariff AA, Mohamed AM, Merican AF (2015). Malaysian growth centiles for children under six years old. Ann Hum Biol, 42(2): 108-115. https://doi.org/10.3109/03 014460.2014 .912679

Brown CJ, Smith G, Shaw L, Parry J, Smith AJ (2007). The erosive potential of flavoured sparkling water drinks. Int $\mathcal{f}$ Paediatr Dent, 17(2): 86-91. https://doi.org/10.1111/ j.1365-263X.2006.00784.x
Browne D, Whelton H, O'Mullane D (2005). Fluoride metabolism and fluorosis. $\mathcal{f}$ Dent, 33(3): 177-186. https://doi.org/10.1016/ j.jdent.2004.10.003

Buzalaf MAR, Levy SM (2011). Fluoride intake of children: Considerations for dental caries and dental fluorosis. Monogr Oral Sci, 22: 1-19. https://doi.org/10.1159/000325101

Chowdhury CR, Shahnawaz K, Kumari PD, Chowdhury A, Gootveld M, Lynch E (2019). Highly acidic $\mathrm{pH}$ values of carbonated sweet drinks, fruit juices, mineral waters and unregulated fluoride levels in oral care products and drinks in India: A public health concern. Perspect Public Health, 139(4): 186-194. https://doi.org/10.1177/1757913918787218

Cochrane NJ, Cai F, Yuan Y, Reynolds EC (2009). Erosive potential of beverages sold in Australian schools. Aust Dent F, 54(3): 238-244. https://doi.org/10.1111/j.1834 $-7819.2009 .01126 . x$

Descoins C, Mathlouthi M, Le Moual M, Hennequin J (2006). Carbonation monitoring of beverage in a laboratory scale unit with on-line measurement of dissolved CO2. Food Chem, 95(4): 541553. https://doi.org/10.1016/j.foodchem .2004 .11 .031

Fojo C, Figueira ME, Almeida CM (2013). Fluoride content of soft drinks, nectars, juices, juice drinks, concentrates, teas and infusions marketed in Portugal. Food Addit Contam Part A Chem Anal Control Expo Risk Assess, 30(4): 705-712. https://doi.org/10.1080/19440049.2013 .785636

Fulgoni VL III, Quann EE (2012). National trends in beverage consumption in children from birth to 5 years: Analysis of NHANES across three decades. Nutr $\mathcal{F}, 11$ : 92. https://doi.org/10.1186/1475-2891-11 $-92$ 
Gan WY, Mohamed SF, Law LS (2019). Unhealthy lifestyle associated with higher intake of sugar-sweetened beverages among Malaysian school-aged adolescents. Int $\mathcal{F}$ Environ Res Public Health, 16(15): 2785. https://doi.org/10.3390/ijerph16152785

Idris AM, Vani NV, Almutari DA, Jafar MA, Boreak N (2016). Analysis of sugars and $\mathrm{pH}$ in commercially available soft drinks in Saudi Arabia with a brief review on their dental implications. F Int Soc Prevent Community Dent, 6(Suppl 3): S192-S196. https://doi.org/10.4103/2231-0762.197190

Institute of Medicine (IOM) (2005). Dietary reference intakes for water, potassium, sodium, chloride and sulfate. Washington, DC: The National Academies Press. https://doi.org/ $10.17226 / 10925$

Jan Mohamed HJ, Loy SL, Mohd Taib MN, Karim NA, Tan SY, Appukutty $M$ et al. (2015). Characteristics associated with the consumption of malted drinks among Malaysian primary school children: Findings from the MyBreakfast study. BMC Public Health, 15: 1322. https://doi.org/10.1186/s12889-015-2666-5

Larsen MJ, Richards A (2002). Fluoride is unable to reduce dental erosion from soft drinks. Caries Res, 36(1): 75-80. https://doi .org/10.1159/000057595

Liu Y, Maguire A, Tianqui G, Yanguo S, Zohoori FV (2017). Fluoride concentrations in a range of ready-todrink beverages consumed in Heilongjiang Province, north-east China. Nutr Health, 23(1): 25-32. https://doi.org/10.1177/ 0260106016685726

Maguire A, Omid N, Abuhaloob L, Moynihan PJ, Zohoori, FV (2012). Fluoride content of ready-to-feed (RTF) infant food and drinks in the UK. Community Dent Oral Epidemiol, 40(1): 26-36. https://doi.org/10 $.1111 / \mathrm{j} .1600-0528.2011 .00632 . \mathrm{x}$
Malaysian Dental Council (2009). Position Document: Use of Fluorides in Malaysia. Retrieved 5 May 2021, from http://mdc .moh.gov.my/uploads/fluorides.pdf

Mantonanaki M, Koletsi-Kounari H, MamaiHomata E, Papaioannou W (2013). Dental erosion prevalence and associated risk indicators among preschool children in Athens, Greece. Clin Oral Investig, 17(2): 585-593. https://doi.org/10.1007/s00784 $-012-0730-4$

Martínez-Mier EA, Cury JA, Heilman JR, Katz BP, Levy SM, Li Y et al. (2011). Development of gold standard ionselective electrode-based methods for fluoride analysis. Caries Res, 45(1): 3-12. https://doi.org/10.1159/000321657

Moynihan PJ (2002). Dietary advice in dental practice. Br Dent f, 193(10): 563-568. https://doi.org/10.1038/sj.bdj.4801628

$\mathrm{Ni}$ Mhurchu C, Vandevijvere S, Waterlander W, Thornton LE, Kelly B, Cameron AJ et al. (2013). Monitoring the availability of healthy and unhealthy foods and non-alcoholic beverages in community and consumer retail food environments globally. Obes Rev, 14 (Suppl 1): 108-119. https://doi.org/10.1111/obr.12080

Omid N, Zohoori FV, Kometa S, Maguire A (2016). Erosive characteristics and fluoride content of cola-type drinks. $\mathrm{Br}$ Dent $\mathcal{F}$, 220(7): 349-355. https://doi.org/10.1038/ sj.bdj.2016.263

Opydo-Szymaczek J, Opydo J (2010). Fluoride content of beverages intended for infants and young children in Poland. Food Chem Toxicol, 48(10): 2702-2706. https://doi.org/ $10.1016 /$ j.fct.2010.06.043

Rahim ZH, Bakri MM, Zakir HM, Ahmed IA, Zulkifli NA (2014). High fluoride and low $\mathrm{pH}$ level have been detected in popular flavoured beverages in Malaysia. Pak $\mathcal{f}$ Med Sci, 30(2): 404-408. https://doi.org/ $10.12669 /$ pims.302.4413 
Reddy A, Norris DF, Momeni SS, Waldo B, Ruby JD (2016). The $\mathrm{pH}$ of beverages in the United States. I Am Dent Assoc, 147(4): 255-263. https://doi.org/10.1016/ j.adaj.2015.10.019

Rirattanapong P, Rirattanapong O (2017). Fluoride content of commercially available ready-to-drink tea in Bangkok, Thailand. Southeast Asian f Trop Med Public Health, 48(3): 690-693.

Rodríguez I, Hardisson A, Paz S, Rubio C, Gutiérrez AJ, Jaudenes JR et al. (2018). Fluoride intake from the consumption of refreshment drinks and natural juices. f Food Compost Anal, 72: 97-103. https://doi.org/10.1016/j.jfca.2018.06.004

Shaharuddin MS, Kamil YM, Ismail YM, Firuz RM, Aizat IS, Yunus AM (2009). Fluoride concentration in Malaysian drinking water. Am Eurasian J Agric Environ Sci, 6(4): 417420.

Shiby VK, Mishra HN (2013). Fermented milks and milk products as functional foods-a review. Crit Rev Food Sci Nutr, 53(5): 482496. https://doi.org/10.1080/10408398.201 0.547398

Townsend JA, Thompson T, Vaughn S, Wang $\mathrm{Y}, \mathrm{Yu}$ Q, Xu X et al. (2019). Analysis of fluoride content in alternative milk beverages. F Clin Pediatr Dent, 43(6): 388392. https://doi.org/10.17796/1053-462543.6 .5
Victory KR, Cabrera NL, Larson D, Reynolds, KA, Latura J, Thomson CA et al. (2017). Comparison of fluoride levels in tap and bottled water and reported use of fluoride supplementation in a United StatesMexico border community. Front Public Health, 5: 87. https://doi.org/10.3389/fpubh .2017 .00087

WHO Multicentre Growth Reference Study Group (2006). WHO child growth standards based on length/height, weight and age. Acta Paediatr, 95(S450): 76-85. https://doi.org/10.1111/j.1651-2227.2006. tb02378.x

World Health Organization (2011). Guidelines for Drinking-water Quality, 4th edn. Geneva: World Health Organization.

Zahid A, Davey C, Reicks M (2017). Beverage intake among children: Associations with parent and home-related factors. Int $\mathcal{F}$ Environ Res Public Health, 14(8): 929. https://doi.org/10.3390/ijerph14080929

Zohoori FV, Maguire A (2018). Are there good reasons for fluoride labelling of food and drink? $\mathrm{Br}$ Dent $\mathcal{F}, 224(4)$ : 215-217. https://doi.org/10.1038/sj.bdj.2018.123 